\title{
Karakter Anak pada Perkawinan Campuran Suku Minangkabau dan Batak di Kelurahan Tanjung Buntung
}

\author{
Erfina Nur Asria Rangkuti, Fatmariza \\ Prodi Pendidikan Pancasila dan Kewarganegaraan \\ FIS Universitas Negeri Padang \\ E-mail: erfinanur24@gmail.com
}

\section{ABSTRAK}

Artikel ini bertujuan untuk mendeskripsikan karakter anak pada perkawinan campuran suku Minangkabau dan Batak di Kelurahan Tanjung Buntung Kecamatan Bengkong Kota Batam, Penelitian ini dilatarbelakangi karena sering ditemukan perbedaan didikan karakter antara anak perempuan dan laki-laki pada perkawinan campuran suku Minangkabau dan Batak di Kelurahan Tanjung Buntung Kecamatan Bengkong Kota Batam. Penelitian ini merupakan penelitian deskriptif kualitatif, adapun data informan dalam penelitian ini adalah: masyarakat, keluarga yang melakukan perkawinan campuran, kepala KUA. Data yang dibutuhkan adalah data primer dan data sekunder yang didapatkan dari observasi, wawancara, dan studi dokumentasi. Uji keabsahan data dilakukan melalui teknik triangulasi, kemudian analisis dengan cara reduksi data, penyajian data, dan selanjutnya disimpulkan untuk penulisan. Hasil penelitian menunjukan bahwa perkawinan campuran antara suku Minangkabau dan Batak memberikan dampak terhadap pembentukan karakter anak, dalam suku batak terkenal dengan bahasa yang keras namun makna nya baik dan lemah lembut, sedangkan dalam suku minangkabau anak diajarkan dengan lemah lembut, namun terkadang dengan bahasa yang sedikit kasar tapi tujuannya baik agar anak memiliki watak yang keras dan pantang menyerah. Dalam perkawinan campuran ini, tidak ada perbedaan derajat antara anak laki-laki maupun perempuan, dalam kedua suku anak laki-laki dan perempuan sama. Oleh karena itu, peran orang tua yang berbeda-beda di setiap keluarga yang mana peran orang tua sangat menentukan kualitas anak dalam berkarakter.

Kata Kunci: perkawinan, karakter anak, Minangkabau, Batak

\section{ABSTRACT}

This article aims to describe the character of children in mixed marriages of Minangkabau and Batak tribes in Tanjung Buntung, Bengkong District, Batam City. This research is motivated because there are often differences in character education between girls and boys in mixed marriages of Minangkabau and Batak tribes in Tanjung Buntung Village. Bengkong District, Batam City. This research is a qualitative descriptive study, while the informant data in this study are: the community, families who have mixed marriages, the 
422 | karakter anak..

head of the KUA. The data needed are primary data and secondary data obtained from observations, interviews, and documentation studies. The data validity test was carried out through triangulation techniques, then analysis by means of data reduction, data presentation, and then the conclusion for writing. The results showed that mixed marriages between Minangkabau and Batak tribes had an impact on the formation of children's character, in the Batak tribe it was known for its strong language but its meaning was good and gentle, while in the Minangkabau tribe children were taught gently, but sometimes with a little language. rude but the intention is good so that the child has a tough and unyielding character. In this mixed marriage, there is no difference in degrees between boys and girls, in both tribes the boys and girls are the same. Therefore, the role of parents is different in each family, where the role of parents determines the quality of the child in character.

\section{Keywords: marriage, children character, Minangkabau, Batak}

(c) (7) (?) This work is licensed under the Creative Commons Attribution-ShareAlike 4.0 International License. EY SA (02020 by author. 


\section{PENDAHULUAN}

Perkawinan campuran dalam arti hukum adat merupakan perkawinan yang terjadi antara suami dan istri yang berbeda suku bangsa, adat dan budaya. Di dalam perkawinan campuran terbentuk karakter anak yang berbeda-beda berdasarkan didikan orang tuanya sehingga anak-anak yang dilahirkan dalam sebuah perkawinan memiliki keunikan. Karakter anak terbentuk dari didikan orang tua, jika terlahir dari orang tua dan keluarga yang berbeda adat, tradisi dan budaya akan berpengaruh terhadap karakter dan perilaku anak. Suku Batak terkenal dengan didikan yang cukup keras sedangkan di Minangkabau anak didik dengan cara ramah tamah dan lembut serta dibawah pengawasan ninik mamak.

Karakter anak dalam Nihayah (2018) dijelaskan bahwa orang tua berperan sebagai penentu perkembangan anak terutama pada seorang ibu. Ibu sebagai pendidik pertama dalam proses pembentukan pengetahuan. Peran keluarga dalam membentuk karakter anak adalah mengembangkan watak, kepribadian, nilai-nilai budaya, nilai keagamaan dan moral. Menurut Rofiq dan Nihayah (2015), pembentukan karakter tidak bisa dilakukan secara maksimal oleh sekolah tanpa kerjasama dari keluarga. Keluarga merupakan pendidik pertama dan utama bagi anak dan menjadi dasar penting dalam pembentukan karakter anak. Anak diibaratkan seperti selembar kertas putih kosong yang harus diisi. Peran orangtua yang sangat dominan mendidik anak semenjak dini, dengan penuh kelembutan dan kasih sayang membangun kebiasaan-kebiasaan positif, mampu menjadi contoh yang baik.

Berdasarkan observasi awal yang dilakukan dengan Bapak Dede Nasution tanggal 22 November 2019 menceritakan perkawinan campuran antara suku Minangkabau dan suku Batak. Dalam pernikahannya mereka dikaruniai 3 orang anak yaitu satu perempuan dan dua laki-laki. Didikan karakter anak perempuan dan laki-laki berbeda. Anak perempuan dididik untuk lebih mengikuti keinginan orangtuanya dibandingkan keinginannya sendiri. Contohnya ketika dia menginginkan untuk kuliah diluar daerah, namun ayahnya tidak mengizinkan anak perempuannya untuk kuliah diluar daerah dikarenakan yang bersangkutan harus selalu berada didalam pengawasan orangtuanya. Sedangkan dua anak laki-laki Dede diperbolehkan untuk mengikuti keinginan mereka dalam memilih masa depannya orang tua selalu 
Batak di Kelurahan Tanjung Buntung Kecamatan Bengkong Kota Batam disebabkan yaitu karena adanya perbedaan didikan antara kedua orangtua dan cara perlakuan kedua orangtua terhadap anak perempuan dan lakilaki.

Berdasarkan hasil temuan yang peneliti temukan dilapangan diketahui bahwa latarbelakang karakter anak pada perkawinan campuran suku Minangkabaudan Batak di Kelurahan Tanjung Buntung Kecamatan Bengkong Kota Batam disebabkan karena adanya perbedaan didikan antara kedua orangtua dan cara perlakuan kedua orangtua terhadap anak perempuan dan laki-laki.

Masyarakat terdiri dari kumpulan individu dan kelompok yang memiliki pandangan dan visi yang berbeda-beda. Karena itu, tidak jarang jika dalam masyarakat terjadi gesekan hingga menjadi konflik. Konflik diawali karena adanya perbedaan dalam struktur sosial masyarakat. Berawal dari konflik, kekerasan dapat terjadi dalam masyarakat Konflik identik dengan kekerasan dan perdamaian. Dalam ilmu sosial, kekerasan memiliki dua pengertian. Pertama, kekerasan merujuk pada semua kejadian dengan unsur utama penggunaan atau ancaman penggunaan kekerasan. Kedua, kekerasan dapat diartikan sebagai "any avoidable impediment to selfrealization" atau segala sesuatu yang menyebabkan orang terhalang untuk mengaktualisasi potensi diri secara wajar.

Perbedaan pendapat pasti terjadi di dalam keluarga. Baik antara pasangan suami istri, anak dengan anak, maupun anak dengan orangtua. Perbedaan pendapat tentu tidak bisa dihindari, dan sebaiknya memang dihadapi saja. Tentu dihadapinya dengan cara yang bijaksana, agar justru dapat memberikan manfaat. Melalui perbedaan pendapat anak dapat memperkuat jati diri dan karakter mereka. Disamping itu, perbedaan pendapat juga dapat membuat kita memahami karakter orang lain. Yang penting masing-masing orang tau bagaimana ia harus bersikap ketika menghadapi perbedaan pendapat.

Cara Perlakuan Kedua Orangtua Terhadap Anak Perempuan Dan Laki-Laki

Hurlock (1999) membagi pola asuh orangtua ke dalam tiga macam yaitu pola asuh permisif, otoriter, dan pola asuh demokratis.

\section{Pola Asuh Permisif}

Pola asuh permisif dapat diartikan sebagai pola perilaku orang tua dalam berinteraksi dengan anak, yang membebaskan 
anak untuk melakukan apa yang ingin dilakukan tanpa mempertanyakan. Pola asuh ini tidak menggunakan aturan-aturan yang ketat bahkan bimbingan pun kurang diberikan. Sehingga tidak ada pengendalian atau pengontrolan serta tuntutan kepada anak. Kebebasan diberikan penuh dan anak diijinkan untuk memberi keputusan untuk dirinya sendiri tanpa pertimbangan orangtua dan berperilaku menurut apa yang diinginkannya tanpa ada kontrol dari orangtua. Menurut Prasetya (Anisa, 2005), bahwa pola asuh permisif atau biasa disebut pola asuh penelantar yaitu dimana orangtua lebih memprioritaskan kepentingannya sendiri, perkembangan kepribadian anak terabaikan, dan orangtua tidak mengetahui apa dan bagaimana kegiatan anak sehari-harinya.

Menurut Dariyo (Annisa, 2005) juga mengatakan bahwa pola asuh permisif yang diterapkan orangtua, dapat menjadikan anak kurang disiplin dengan aturanaturan sosial yang berlaku. Namun bila anak mampu menggunakan kebebasan secara bertanggung jawab, maka dapat menjadi seorang yang mandiri, kreatif, dan mampu mewujudkan aktualitasnya.

\section{Pola Asuh Otoriter}

Pola asuh otoriter ini dapat menimbulkan dampak hilangnya kebebasan pada anak, inisiatif dan aktivitasnya menjadi kurang, sehingga anak menjadi tidak percaya diri pada kemampuannya. Senada dengan Hurlock, Dariyo dalam (Anisa, 2005) mengatakan bahwa anak yang dididik dalam pola asuh otoriter, cenderung memiliki kedisiplinan dan kepatuhan yang semu.

\section{Pola Asuh Demokratis}

Dalam pola asuh ini tumbuh rasa tanggung jawab pada anak dan mampu bertindak sesuai dengan norma yang ada. Dariyo (Anisa, 2005) mengatakan bahwa pola asuh demokratis ini, disamping memiliki sisi positif dari anak, terdapat juga sisi negatifnya.

Peran orang tua dalam membentuk karakter anak sangat penting. Orang tua merupakan tempat bimbingan pertama dalam membentuk karakter anak. Dengan begitu sebagai orang tua jangan sampai membiarkan pertumbuhan anak berjalan tanpa bimbingannya, sikap pertama yang harus dilakukan orangtua kepada anaknya adalah menunjukkan rasa kasih sayang tetapi tidak berlebihan, agar mereka merasa aman dan terlindungi. Peran orang tua dalam membentuk karakter anak harus dimulai sejak dini hingga ia beranjak dewasa karena akan mempengaruhi masa 
depannya. Adapun beberapa hal yang harus dilakukan dalam membentuk karakter anak diantaranya mengajarkan tingkah laku sesuai dengan agama yang dianut, mendidik anak dengan keteladanan, mengajarkan anak untuk memilih lingkungan mana yang baik dan mana yang buruk, memberikan kebiasaan dengan halhal yang baik.

Tidak hanya hal diatas saja yang dapat dilakukan, secara terperinci Zubaedi mengajarkan beberapa cara yang dapat dilakukan oleh orangtua dalam membentuk karakter anak yaitu: Orang tua merupakan peran penting dalam membentuk karakter anak, Orang tua harus pandai mengatur waktu untuk memperhatikan anak, Mampu sebagai contoh yang baik., Membuktikan perkataan yang diucapkan, Selalu memantau apa yang dilakukan anak, Memberikan anak waktu untuk mengungkapkan isi hati, kemudian Jika anak melakukan kesalahan menegur tegas namun sayang.

Kemudian sikap toleransi juga merupakan didikan karakter yangt harus diberikan kepada anak sebab tanpa toleransi anak akan sulit untuk menghargai seseorang. Toleransi adalah tindakan yang tidak membedakan satu dengan yang lain. Kita bisa mendapatkan kesetaraan hak dalam berpendapat. Dengan adanya perkawinan campuran anak akan lebih mudah untuk mengerti apa arti dari toleransi. Walaupun anak berasal dari perkawinan campuran suku minangkabau dan batak, orang tua harus selalu memberikan dukungan dan kesempatan anak dalam mewujudkan keinginannya.

Dari hasil temuan di lapangan diketahui bahwa yang melatarbelakangi karakter anak pada perkawinan campuran suku Minangkabau dan Batak diKelurahan Tanjung Buntung Kecamatan Bengkong Kota Batam adalah peran orangtua yang berbeda-beda di setiap keluarga yang mana peran orangtua sangat menentukan kualitas anak dalam berkarakter. Karakter anak dalam Nihayah (2018) mengatakan bahwa orang tua berperan sebagai penentu perkembangan anak terutama pada seorang ibu. Ibu sebagai pendidik pertama dalam proses pembentukan pengetahuan. Peran keluarga dalam membentuk karakter anak adalah mengembangkan watak, kepribadian, nilai-nilai budaya, nilai keagamaan dan moral.

Menurut Prasetyo (2011) menjelaskan bahwa ada dua faktor yang mempengaruhi pembantukan karakter, yaitu bawaan dari dalam diri anak dan pandangan anak 
terhadap dunia yang dimilikinya, seperti pengetahuan, pengalaman, prinsip-prinsip moral yang diterima, bimbingan, pengarahan dan interaksi (hubungan) orang tua anak. Proses pembentukan karakter diawali dengan kondisi pribadi ibuayah sebagai figur yang berpengaruh untuk menjadi panutan, keteladanan, dan diidolakan atau ditiru anak-anak. Sikap dan perilaku ibu-ayah seharihari merupakan pendidikan watak yang terjadi secara berkelanjutan, terus-menerus dalam perjalanan umur anak. Sudaryanti (2012) mengatakan bahwa pembentukan karakter (character building) dapat dilakukan melalui pendidikan budi pekerti yaitu melibatkan aspek pengetahuan (cognitif), perasaan (feeling), dan tindakan (action).

Menurut Hyoscyamina (2011), keluarga tanpa kekerasan adalah salah satu solusi efektif untuk membuat seorang anak merasa nyaman, damai, tentram di rumah, namun yang terjadi belakangan ini para orangtua cenderung mendidik anak-anak mereka dengan emosi tinggi, kurang perhatian bahkan menelantarkan mereka. Ada juga orang tua yang merasa cukup memberikan perhatian kepada anak dengan menuruti segala keinginan mereka. Kemudian memenuhi kebutuhan materi tetapi soal pendidikan, terutama akhlak mulia, kasih sayang dinomorduakan.

Hasilnya anak akan memiliki sifat yang tidak baik. Perkembangan kepribadian anak dapat dikendalikan dan dibentuk dengan bimbingan dan bantuan dari keluarga, karena keluarga tempat pendidikan pertama kali bagi anak. Jadi kita tidak boleh menyalahkan faktor lingkungan yang dapat menyebabkan kepribadian seseorang itu buruk. Anak masih membutuhkan orangtua dan kehangatan dalam keluarga yang membantu proses perkembangan otak baik dari segi akademis maupun non akademis. Karakter seorang anak terbentuk pada saat anak berusia tiga hingga sepuluh tahun. Adalah merupakan tugas orangtua untuk menentukan input seperti apa yang masuk kedalam pikiran anak demi membentuk karakter anak yang berkualitas.

\section{KESIMPULAN}

Peran orang tua dalam membentuk karakter anak pada perkawinan campuran suku Minangkabau dan Batak di Keluharan Tanjung Buntung Kecamatan Bengkong Kota Batam berbeda di setiap keluarga yang mana peran orangtua sangat menentukan kualitas anak dalam berkarakter. Orang tua memiliki peran ganda dalam membentuk 
karakter anak dan memberikan pendidikan karakter yang baik bagi anak. Karakter anak terbentuk dari tradisi, budaya, peran orang tua dalam memberikan didikan dan memebentuk karakter anak. Anak yang terlahir dari perkawinan campuran Suku Minangkabau dan Batak akan melahirkan anak dengan karakter yang keras namun bertanggungjawab dan sopan.

\section{DAFTAR PUSTAKA}

Anisa, Siti. 2005. Kontribusi Pola Asuh Orang Tua Terhadap Kemandirian Siswa Kelas II SMA Negeri 1 Balapulang Kabupaten Tegal Tahun Pelajaran 2004/2005. Skripsi: Universitas Negeri Semarang.

Bungin, Burhan. 2003. Analisa Data Penelitian Kualitatif:

Pemahaman Filosofis Dan Metodologis Ke Arah Penguasaan Model Aplikasi. Jakarta: Raja Grafindo Persada.

Haris Hardiansyah. 2014. Metedologi Penelitian Kualitatif. Jakarta Selatan: Selemba Humanika.

Hyoscyamina, Darosy Endah. 2011. Peran Keluarga Dalam Membangun Karakter Anak. Jurnal Psikologi. Vol.10. N0.2. Nihayah, Ismatun., dkk. 2018. Pengaruh Motivasi Keluarga Terhadap Prestasi Belajar Siswa: Studi Kasus di MTs
Al-Azhar Tuwel. Jurnal Pendidikan Islam. Vol.8. No.2. Prasetyo, Nana. 2011. Membangun Karakter Anak Usia Dini. Jakarta: Direktorat Pembinaan Anak Usia Dini. Pratiwi, Ni Kadek Santya. 2018. Pentingnya Peran Orang Tua Dalam Pendidikan Karakter Anak Usia Sekolah Dasar. Jurnal Pendidikan Dasar. Vol.3. No.1. ISSN: 2527-5455.

Sarwono, Sarlito Wirawan. 2010. Teori-Teori Psikologi Sosial. Jakarta: Raja Grafindo Persada.

Sudaryanti. 2012. Pentingnya Pendidikan Karakter Bagi Anak Usia Dini. Jurnal Pendidikan Anak. Vol.1. Edisi 1Juni 2012.

Zubaedi. 2011. Pendidikan Karakter: Konsep Dan Aplikasinya Dalam Lembaga Pendidikan. Jakarta: Kencana. 